\title{
Phenolic compounds as antioxidants and chemopreventive drugs from Streptomyces cellulosae strain TES17 isolated from rhizosphere of Camellia sinensis
}

\author{
Riveka Rani ${ }^{1}$, Saroj Arora ${ }^{2}$, Jeevanjot Kaur ${ }^{2}$ and Rajesh Kumari Manhas ${ }^{1 *}$
}

\begin{abstract}
Background: Oxidative stress in an intracellular environment created by the accumulation of reactive oxygen species results in oxidative damage to biomolecules which ultimately become a hallmark for severe diseases like cancer, aging, diabetes, and cardiovascular and neurodegenerative diseases.

Methods: Various in vitro assays were employed to assess the antioxidant potential of strain, DNA protective activity was demonstrated using DNA nicking assay and cytotoxicity of the extract was evaluated using MTT assay. Further identification of the compounds was done using UPLC analysis.

Results: The extract of Streptomyces cellulosae strain TES17 demonstrated significant antioxidant activity with percentage inhibition of $78.47 \pm 0.23,91.08 \pm 0.98$ and $82.08 \pm 0.93$ for DPPH, ABTS and superoxide radical assays at $5 \mathrm{mg} / \mathrm{mL}$, respectively. Total antioxidant and reducing power were found to be $76.93 \pm 0.76$ and $231.96 \pm 0.51 \mathrm{mg}$ AAE/100 mg of dry extract, respectively. Moreover, the extract was shown to inhibit lipid peroxidation upto $67.18 \pm 1$. $9 \%$ at $5 \mathrm{mg} / \mathrm{mL}$. TPC and TFC measured in the extract was $55 \mathrm{mg} \mathrm{GAE} / 100 \mathrm{mg}$ and $11.17 \pm 4.05 \mathrm{mg}$ rutin/100 mg, respectively. The protective nature of the TES17 extract to oxidative stress induced damaged DNA was shown by percentage of supercoiled DNA i.e. Form I was increased from 26.38 to $38.20 \%$ at concentrations ranging from $2 \mu \mathrm{g}$ to $10 \mu \mathrm{g}$. TES17 extract also showed the cytotoxic activity against lung cancer cell line with $74.7 \pm$ $1.33 \%$ inhibition whereas, limited toxicity was observed against normal cell line with percentage viability of $87.71 \pm 6$. 66 at same concentration $(30 \mu \mathrm{g} / \mathrm{mL}$ ) tested. The antioxidant capacity of extract was well correlated with its TPC and TFC and this in turn was in keeping with the UPLC analysis which also revealed the presence of phenolic compounds that were responsible for the antioxidant and cytotoxic potential of S. cellulosae strain TES17.
\end{abstract}

Conclusions: The present study describes that S. cellulosae strain TES17 isolated from the rhizosphere of Camellia sinensis (tea) plant; produces potent compounds with antioxidant activity, further might be developed into therapeutic drugs to combat oxidative stress.

Keywords: Oxidative stress, Streptomyces cellulosae, Rhizosphere, Camellia sinensis, Antioxidant, Phenolic compounds, Cytotoxicity

\footnotetext{
* Correspondence: rkmanhas@rediffmail.com; riveka.microrsh@gndu.ac.in 1 Department of Microbiology, Guru Nanak Dev University, Amritsar, Punjab 143005, India

Full list of author information is available at the end of the article
} 


\section{Background}

Reactive Oxygen Species (ROS) are constantly generated as a byproduct during the electron transport chain in mitochondria [1], the bane to all aerobic species. It is plausible that at low concentration, ROS play an important role in cell signaling including apoptosis and gene expression [2]. A balance between production and removal of ROS is paramount to the survival of all aerobic life forms. However, the disequilibrium of oxidation status due to accumulation of free radicals creates an oxidative stress in intracellular milieu [3]. Oxidative stress has been implicated in physiological aging [4], diabetes [5], development of neurodegenerative diseases such as Parkinson's disease and Alzheimer's disease [6], cardiovascular diseases [7] and cancer [8].

In order to antagonize the oxidative stress, antioxidants play an important role in the survival of aerobic species. Antioxidants act as electron donors to the highly reactive species and make them stable [9]. Synthetic antioxidants such as butylated hydroxyanisole (BHA), butylated hydroxytoluene (BHT) and propyl gallate (PG) have been used but their use is being restricted due to their low solubility, moderate antioxidant activity and negative health effects [10]. In view of the importance of antioxidants, demand for natural antioxidants with potential beneficial effects on human health is increasing [11, 12]. Thus far, plants have been the main source of natural antioxidants owing to their high antioxidant content $[13,14]$. However, microbial species are known as an immense reservoir of pharmaceutically active compounds and has gained increasing attention in drug discovery $[15,16]$.

In the field of microbial drug discovery, actinobacteria have been greatly studied for their ability to make a wide range of novel and highly potent bioactive compounds; accounting for $45 \%$ of all the discovered bioactive metabolites $[17,18]$. The dominant and best-studied genus of this phylum is Streptomyces which has a remarkable contribution to mankind since the golden era of drug discovery was initiated with the discovery of streptomycin from Streptomyces griseus [12, 19, 20]. At present, Streptomyces accounts for $70-80 \%$ of relevant bioactive metabolites produced by more than 500 species with diverse biological activities such as antibacterial, antifungal, antioxidant, anticancer, anti-inflammatory and antiparasitic [21]. However, there are very limited studies on Streptomyces with respect to phenolic compounds as antioxidants. So, there is need to screen more streptomycetes with potent free radical scavenging activity. Rhizospheric Streptomyces have great importance in search of novel species and new bioactive compounds with diverse biological activities. Due to the presence of various complex interactions in the rhizosphere, microorganisms have coevolved with plants and show similar type of structure and function [22]. Various studies reported the potential of Streptomyces spp. from one such valuable region [23-25].

In the light of this, during our screening programme for isolation of rhizospheric Streptomyces spp. exhibiting different bioactivities, a potent streptomycete isolate indexed as TES17 was isolated from rhizospheric soil of tea (Camellia sinensis L.; family Theaceae) plant collected from Palampur (Himachal Pradesh, India). Tea is the most popular and widely consumed beverage in world second to water [26]. The numerous health benefits associated with tea consumption have been attributed to the free radical-scavenging capabilities of the most abundant compounds such as tea catechins (up to $30 \%$ of dry weight), quercetin and myricetin [27-29].

Keeping this in mind, the tea rhizospheric soil strain TES17 was evaluated for antioxidant activities using various in vitro free radical scavenging assays and identified using polyphasic approach. To further support, DNA damage protective activity of Streptomyces TES17 was assessed using an in vitro DNA nicking assay, and cytotoxicity of the extract was evaluated on lung cancer cell line. The chemical constituents of the extract responsible for antioxidant activity were determined through ultra high-pressure liquid chromatography (UPLC) analysis.

\section{Methods}

Sample collection and isolation of S. cellulosae strain TES17 In July 2013, strain TES17 was isolated from soil sample collected from rhizosphere of tea (Camellia sinensis) plant, from the designated site TES- PM $\left(32^{\circ} 6^{\prime} 37.9^{\prime \prime} \mathrm{N}\right.$ $76^{\circ} 32^{\prime} 10.4^{\prime \prime}$ E), situated in Palampur, Himachal Pradesh (India). The plant has been formally identified by Department of Botanical and Environmental Sciences, Guru Nanak Dev University, Amritsar. The isolation of TES17 was done using the protocol described by Sharma et al. [30]. The isolate was maintained on Starch Casein Nitrate Agar medium (SCNA; g/L): starch 10.0, casein 0.3, $\mathrm{KNO}_{3} 2.0, \mathrm{NaCl} 2.0, \mathrm{~K}_{2} \mathrm{HPO}_{4} 2.0, \mathrm{MgSO}_{4} .7 \mathrm{H}_{2} \mathrm{O}$ $0.05, \mathrm{CaCO}_{3}$ 0.02, $\mathrm{FeSO}_{4} .7 \mathrm{H}_{2} \mathrm{O} 0.01$ and agar 20.0) slants at $4{ }^{\circ} \mathrm{C}$ in the refrigerator and as spore suspensions in $20 \% v / v$ glycerol at $-70{ }^{\circ} \mathrm{C}$ in an ultra-low temperature freezer.

\section{Characterization and identification of isolate TES17 using polyphasic approach \\ Phenotypic and biochemical characterization}

Various cultural and morphological properties such as sporulation, pigmentation of aerial and substrate mycelia and soluble pigmentation in medium which are highly characteristic and useful in the classification of the genus Streptomyces [31] were observed by inoculating the TES17 on SCNA and different ISP media (ISP-1, ISP-2, 
ISP-3, ISP-4, ISP-5, ISP-6 and ISP-7) as per methods prescribed in International Streptomyces Project [32]. Morphological properties of the isolate were observed by the light microscope (Olympus) at 100X, and spore chain and spore surface morphology was determined by scanning electron microscopy (Carl Zeiss model EVOLS 10). Physiological tests were performed by growing the strain on SCNA at different temperatures $\left(20-50{ }^{\circ} \mathrm{C}\right)$, $\mathrm{pH}(5.0-12.0)$ and different $\mathrm{NaCl}$ concentrations (0-20\% $w / v)$. Assimilation of sugars as carbon sources (1\%) was studied according to Shirling and Gottlieb [32]. Dglucose, arabinose, xylose, adonitol, rhamnose, cellobiose, lactose, malonate, raffinose and trehalose (1\%) (HiMedia, India) were added to the basal medium after filter sterilization. Catalase production, citrate utilization, hydrolysis of urea, esculin, casein, gelatin and starch were performed using the method given by Cowan and Steel [33]. Indole production and Methyl red and Vogues Proskauer (MR-VP) tests were performed as recommended by Holding and Collee [34]. Nitrate reduction was investigated according to Lanyi [35].

\section{Genomic characterization based on 16S rRNA gene sequencing}

For $16 \mathrm{~S}$ rRNA gene sequencing, the genomic DNA of the isolate was extracted following the method given by Marmur [36], and amplification was performed by polymerase chain reaction (PCR) using primers 27f (5'-AG AGTTTGATCCTGGCTCAG-3') and 1492r (5'-AG AAAGGAGGTGATCCAGGC-3'). The amplified PCR product was purified using QIA quick gel extraction kit (Qiagen, Germany). The purified PCR product got sequenced from Institute of Microbial Technology (IMTECH), Chandigarh, India. Identification of phylogenetic neighbors and calculation of pair wise $16 \mathrm{~S}$ rRNA gene sequence similarities were achieved using the EzTaxon server (http://www.ezbiocloud.net) [37]. The almost complete sequence (1445 bp) was aligned using Clustal W Program. Phylogenetic trees were constructed according to the neighbor joining, maximum-parsimony and maximum likelihood algorithms using bootstrap values based on 1000 replications with the MEGA 6.0 software [38, 39].

\section{Extract preparation of strain TES17}

The fermentation process was carried out by inoculating the production medium with seed culture. To prepare seed culture, the seven-day old actinobacterial plate was inoculated in $100 \mathrm{~mL}$ of SCN broth. After $48 \mathrm{~h}$, inoculum (2\%) was aseptically transferred to $250 \mathrm{~mL}$ of Erlenmeyer flask containing $50 \mathrm{~mL}$ of the production medium same as seed medium and incubated for four days at $28{ }^{\circ} \mathrm{C}$ under shaking at $180 \mathrm{rpm}$. After fermentation, the broth was centrifuged at $10,000 \mathrm{X}$ g for $20 \mathrm{~min}$ at $4{ }^{\circ} \mathrm{C}$ and the supernatant was separated. For the extraction of bioactive compound/s, the supernatant was extracted with ethyl acetate twice in the ratio of 1:1 (supernatant: solvent) using separating funnel. The organic phase was then concentrated to dryness using rotavapor (BUCHI) at $40{ }^{\circ} \mathrm{C}$. The crude extract obtained was dissolved in methanol prior to further analysis.

\section{Antioxidant potential of $S$. cellulosae strain TES17 extract DPPH radical scavenging assay}

Antioxidant activity of the TES17 extract was examined using DPPH (2,2-diphenyl-1-picrylhydrazyl) assay according to the method given by Kumar et al. [10] with minor modifications. Varying concentrations $(0.5-5 \mathrm{mg} /$ $\mathrm{mL}$ ) of TES17 extract were mixed with freshly prepared $0.002 \%(w / v)$ DPPH (Sigma-Aldrich) in methanol. The reaction mixture was incubated in the dark at room temperature for $30 \mathrm{~min}$ prior to the measurement of absorbance at $517 \mathrm{~nm}$ with a microplate reader. Vitamin C was used as the positive control. The percentage $\mathrm{DPPH}$ radical inhibition was computed according to the following formula:

\section{DPPH Scavenging Activity $(\%)=[($ Ao-Ae $) /$ Ao $] \times 100$}

Where Ao is the absorbance of the control and Ae is the absorbance of the metabolite/standard.

\section{ABTS radical scavenging activity}

The 2,2' - azino-bis (3-ethylbenzothiazoline-6-sulfonic acid) (ABTS) radical scavenging assay was conducted according to the method described by $\mathrm{Re}$ et al. [40] with small modifications. The ABTS free radical solution $(190 \mu \mathrm{L})$ was reacted with the series of different concentrations $(10 \mu \mathrm{L}, 0.5-5 \mathrm{mg} / \mathrm{mL})$ of the TES17 extract in 96-well microtitre plate. The ABTS free radical solution was prepared via reacting ABTS stock solution (7 mM) with potassium persulphate $(2.45 \mathrm{mM})$ in dark for $24 \mathrm{~h}$. The prepared ABTS radical solution was diluted to an absorbance of $0.7 \pm 0.2$ prior to performing the assay. The reaction was left in the dark at room temperature for $3 \mathrm{~min}$ before taking the absorbance at $743 \mathrm{~nm}$. Ascorbic acid was used as positive control. The percentage of ABTS radical inhibition activity was indicated by the decrease in the absorbance of color produced by ABTS radical solution and was determined using the formula:

$$
\text { ABTS Scavenging Activity }(\%)=[(\text { Ao-Ae }) / \text { Ao }] \times 100
$$

Where Ao is the absorbance of the control and Ae is the absorbance of the metabolite/standard.

\section{Superoxide anion scavenging assay}

This assay was proposed by Nishikimi et al. [41] and used for measuring the superoxide anion scavenging 
potential. The process of generation of superoxide anions was non-enzymatic in a PMS-NADH system constituted of phenazine methosulphate and reduced nicotinamide adenine dinucleotide. Blue colored formazan dye was formed by reduction of nitro blue tetrazolium. In this method, TES17 extract $(0.5-5 \mathrm{mg} / \mathrm{mL})$ was mixed with $156 \mu \mathrm{M}$ NADH $(1 \mathrm{~mL}), 60 \mu \mathrm{M}$ NBT $(1 \mathrm{~mL})$ and $468 \mu \mathrm{M}$ phenazine methosulphate $(1 \mathrm{~mL})$ in phosphate buffer $(\mathrm{pH}=8.3)$. PMS was added for initiation of reaction mixture followed by its incubation at $25{ }^{\circ} \mathrm{C}$ for $10 \mathrm{~min}$. Gallic acid was used as positive control. The absorbance was read at $560 \mathrm{~nm}$ and the percentage inhibition was calculated using the formula:

$$
\begin{aligned}
& \text { Superoxide Anion Scavenging Activity (\%) } \\
& \quad=[(\text { Ao-Ae }) / \mathrm{Ao}] \times 100
\end{aligned}
$$

Where Ao is the absorbance of the control and Ae is the absorbance of the metabolite/standard.

\section{Phosphomolybdenum assay}

The molybdate ion reducing ability of the extracts was assessed according to the method proposed by Prieto et al. [42] with small changes. In short, TES17 extract $(5 \mathrm{mg} / \mathrm{mL})$ was mixed with $900 \mu \mathrm{L}$ of reagent solution which was comprised of $0.6 \mathrm{M}$ sulphuric acid, $28 \mathrm{mM}$ sodium phosphate and $4 \mathrm{mM}$ ammonium molybdate. This mixture was kept for incubation for $90 \mathrm{~min}$ at $95{ }^{\circ} \mathrm{C}$ and followed by cooling at room temperature. The absorbance was read at $695 \mathrm{~nm}$. The standard curve was plotted with $20-200 \mu \mathrm{g} / \mathrm{mL}$ concentrations of ascorbic acid. The total antioxidant capability was calculated from the standard curve and expressed as mg Ascorbic Acid Equivalents (AAE)/ $100 \mathrm{mg}$ dry weight of extracts.

\section{Reducing power assay}

The total reducing power of TES17 extract was measured as described by Oktay et al. [43]. The assay measures the formation of a blue colored complex with potassium ferricyanide $\left(\mathrm{K}_{3} \mathrm{Fe}(\mathrm{CN})_{6}\right)$, trichloroacetic acid and ferric chloride $\left(\mathrm{FeCl}_{3}\right)$. Briefly, TES17 extract $(5 \mathrm{mg} /$ $\mathrm{mL})$ was reacted with phosphate buffer $(2.5 \mathrm{~mL}, 0.2 \mathrm{M}$, $\mathrm{pH}$ 6.6) and potassium ferricyanide $(2.5 \mathrm{~mL}, 1 \% \mathrm{w} / \mathrm{v})$. The mixture was incubated for $20 \mathrm{~min}$ at $50{ }^{\circ} \mathrm{C}$ and then added a small portion of trichloroacetic acid $(2.5 \mathrm{~mL}$, $10 \% w / v)$. The resulting mixture was centrifuged at $10000 \mathrm{X} \mathrm{g}$ for $10 \mathrm{~min}$. The collected supernatant $(2.5 \mathrm{~mL})$ was mixed with distilled water $(2.5 \mathrm{~mL})$ prior to the addition of $\mathrm{FeCl}_{3}(500 \mu \mathrm{L}, 0.1 \% \mathrm{w} / v)$. The absorbance was taken at $700 \mathrm{~nm}$ spectrophotometrically and compared with Vitamin $\mathrm{C}$ which was used as positive control. The reducing capability was calculated from the standard curve and expressed as mg Ascorbic Acid Equivalents (AAE) / $100 \mathrm{mg}$ dry weight of extracts.

\section{Lipid peroxidation assay}

The method proposed by Dasgupta and De [44] with slight modifications was followed to estimate the amount of malondialdehyde (MDA). The protective ability of extract was demonstrated by mixing the different concentrations of TES17 extract $(0.5-5 \mathrm{mg} / \mathrm{mL})$ with $10 \%$ egg yolk $(500 \mu \mathrm{L})$. For initiation of lipid peroxidation, $50 \mu \mathrm{L}$ of $7 \mathrm{mM} \mathrm{FeSO}_{4}$ was added and incubated at $37{ }^{\circ} \mathrm{C}$ for $30 \mathrm{~min}$. The process of lipid peroxidation was checked by the formation of thiobarbituric acid reactive substances (TBARS). TBARS were determined by adding ice-cold 20\% trichloroacetic acid (TCA; $50 \mu \mathrm{L}), 0.8 \%(w /$ v) TBA $(1.5 \mathrm{~mL})$ and $20 \%$ acetic acid $(1.5 \mathrm{~mL}, \mathrm{pH} 3.5)$ to the reaction mixture. The reaction mixture was heated at $100{ }^{\circ} \mathrm{C}$ for $60 \mathrm{~min}$. After that, the reaction mixture was cooled and centrifuged at $3000 \mathrm{X}$ g for $10 \mathrm{~min}$ and the product was measured by spectrophotometer at $532 \mathrm{~nm}$. The percentage inhibition was calculated with the formula:

$$
\begin{aligned}
& \text { Inhibition of the lipid peroxidation }(\%) \\
& \quad=[(\text { Ao-Ae }) / \mathrm{Ao}] \times 100
\end{aligned}
$$

Where Ao is the absorbance of the control and Ae is the absorbance of the metabolite/standard.

\section{Estimation of Total phenolic content (TPC) with Folin- Ciocalteu's reagent method}

The total phenolic content in the TES17 extract was estimated using Folin-ciocalteau method in 96-well microtitre plate according to $\mathrm{Yu}$ et al. [45] with slight modifications. $10 \mu \mathrm{L}$ of the TES17 extract $(5 \mathrm{mg} / \mathrm{mL})$ was mixed with $100 \mu \mathrm{L}$ of Folin Ciocalteau Reagent. After $5 \mathrm{~min}$ of incubation at room temperature, $80 \mu \mathrm{L}$ of $7.5 \%$ sodium carbonate $\left(\mathrm{Na}_{2} \mathrm{CO}_{3}\right)$ was added to each well followed by $30 \mathrm{~min}$ incubation at room temperature in dark. The absorbance was measured with a microplate reader at $750 \mathrm{~nm}$. The calibration curve of gallic acid (used as a standard) was plotted using the calibration curve and the amount of TPC was estimated as mg of Gallic Acid Equivalents (GAE)/100 mg of the extract.

\section{Estimation of Total flavonoid content (TFC) based on Aluminium-Flavanoid complexes formation method}

The TFC in TES17 extract was quantified using the 96 well plate method described by Tan et al. [3]. In this, $100 \mu \mathrm{L}$ of distilled water was added into each of the well, followed by $25 \mu \mathrm{L}$ of the test sample $(5 \mathrm{mg} / \mathrm{mL})$ and $10 \mu \mathrm{L}$ of $5 \%$ sodium nitrite $\left(\mathrm{NaNO}_{2}\right)$. After $5 \mathrm{~min}$ of incubation, $15 \mu \mathrm{L}$ of $10 \%$ aluminum chloride $\left(\mathrm{AlCl}_{3}\right)$ was added and the reaction mixture was allowed to stand for 6 min before the addition of $50 \mu \mathrm{L}$ of $1 \mathrm{M} \mathrm{NaOH}$. Next, $50 \mu \mathrm{L}$ of distilled water was added to each well of the microtiter plate and mixed well. The absorbance was 
recorded immediately at $510 \mathrm{~nm}$ using microplate reader. Catechin was used as positive control and used for plotting the calibration curve. Total flavonoid content (TFC) was measured as mg of catechin equivalent/ $100 \mathrm{mg}$ dried weight of the extract.

\section{DNA nicking assay}

This assay was performed according to the method given by Lee et al. [46]. This method was used to evaluate the potential of TES17 extract to protect super coiled pBR 322 plasmid from destroying effects of hydroxyl radicals produced by Fenton's reagent. The reaction mixture constituted of $1 \mu \mathrm{L}$ plasmid DNA $(50 \mu \mathrm{g} / 100 \mu \mathrm{L}), 10 \mu \mathrm{L}$ Fenton's reagent $\left(30 \mathrm{mM} \mathrm{H} \mathrm{H}_{2} \mathrm{O}_{2}, 50 \mu \mathrm{M}\right.$ ascorbic acid, and $80 \mu \mathrm{M} \mathrm{FeCl}_{3}$ ) and different concentrations of extract $(200 \mu \mathrm{g} / \mathrm{mL}, 400 \mu \mathrm{g} / \mathrm{mL}, 600 \mu \mathrm{g} / \mathrm{mL}, 800 \mu \mathrm{g} / \mathrm{mL}$ and $1000 \mu \mathrm{g} / \mathrm{mL}$ ) and distilled water to make the final volume up to $20 \mu \mathrm{L}$. An equal volume of distilled water was added in place of Fenton's reagent in the negative control. It was followed by incubation at $37{ }^{\circ} \mathrm{C}$ for $30 \mathrm{~min}$. The analysis of DNA was done on $1 \%$ agarose gel electrophoresis. The positive control used was rutin. Densitometric analysis was done to examine the DNA damage quantitatively with the help of GelQuant.NET (Version 1.8.2; BiochemLabSolutions.com) software. The percentage of different forms of DNA i.e. supercoiled (Form I), single standed nicked (Form II) and double stranded nicked and linear (Form III) was calculated.

\section{In vitro cytotoxic assay}

\section{Cell culture maintenance and treatment}

HEK-293 T (Human Embryonic Kidney normal cell line) and A549 (adenocarcinoma lung cancer cell line) were obtained from National Centre for Cell Science (NCCS), Pune (India) and were maintained in complete growth medium Roswell Park Memorial Institute (RPMI) 1640 supplemented with $10 \%$ Fetal Bovine Serum along with antibiotics $(100 \mu \mathrm{g} / \mathrm{mL}$ streptomycin and $100 \mathrm{Units} / \mathrm{mL}$ penicillin). The cell lines were maintained at $37{ }^{\circ} \mathrm{C}$ in an environment of $90 \%$ relative humidity and $5 \% \mathrm{CO}_{2}$. To check the degree of confluency and absence of bacterial and fungal contamination, cultures were viewed using trypan blue dye in phase contrast microscope.

\section{Measurement of cell viability using 3-(4,5-Dimethylthiazol- 2yl)-2,5-diphenyl tetrazolium bromide (MTT) assay}

The cytotoxicity of the TES17 extract was examined using MTT assay following the protocol previously described by Mossman [47]. It is a colorimetric assay that measures the reduction of yellow colored dye MTT by mitochondrial enzyme viz., succinate dehydrogenase. MTT enters mitochondria of the cell where it is reduced to an insoluble purple colored formazan product. The cells are then solubilized with an organic solvent like isopropanol or DMSO and the released solubilized formazan product is measured spectrophotometrically. Since the reduction of MTT can occur only in living cells, this assay is regarded as a measure of the viability of the cells. Cells (5000 cells/well) were seeded in the 96 well microtiter plate and allowed to adhere overnight. Varying concentrations of TES17 extract (30, 50, 100, 250 and $500 \mu \mathrm{g} / \mathrm{mL}$ ) were then added to each well and further incubated for $42 \mathrm{~h}$. After that, $100 \mu \mathrm{L}$ of $0.5 \mathrm{mg} /$ $\mathrm{mL}$ of MTT dye (Sigma-Aldrich) was added to each well and the plates were incubated at $37{ }^{\circ} \mathrm{C}$ in humidified environment with $5 \% \mathrm{CO}_{2}$ for $4 \mathrm{~h}$. Then, the complete medium was aspirated from the wells and blue formazan crystals formed by MTT reaction were dissolved in $100 \mu \mathrm{L}$ of DMSO. The color was measured at $595 \mathrm{~nm}$ using a microplate reader. The proliferation of cells under treatment was assessed according to following formula:

$$
\text { Cell viability }(\%)=[\text { Ae } / \text { Ao }] \times 100
$$

Where Ao is the absorbance of the untreated cells (only medium) and Ae is the absorbance of the treated cells (with extract).

\section{Determination of phenolic compounds: Ultra performance liquid chromatography (UPLC) analysis}

The UPLC analysis was performed on Nexera UHPLC (Shimadzu) system. The system was equipped with LC30 AD quaternary gradient pump, SPD-M20 A diode array detector (DAD), CBM-20 A Communication Bus Module, CTO-10 AS VP column oven, DGU-10 $\mathrm{A}_{5}$ prominence degasser, SIL-30 AC Nexera auto sampler, C-18 column of dimensions $150 \times 4.6 \times 5 \mu \mathrm{m}$ particle size, and combination of water and $70 \%$ methanol as mobile phase at flow rate of $1 \mathrm{~mL} / \mathrm{min}$ were used for analysis. The column temperature was maintained at $27{ }^{\circ} \mathrm{C}$ and the run time of the sample was $26 \mathrm{~min}$. The constituents were identified by comparison of their retention time with standards available.

\section{Statistical analysis}

The antioxidant assays were performed in triplicate. Results were expressed in mean \pm standard deviation (SD). SPSS statistical analysis software (Version 20.0; IBM SPSS) was used to analyze the data. Regression studies were carried out along with the analysis of multiple comparisons by using one-way analysis of variance (ANOVA) with post hoc Tukey's test. Statistical significance was considered at $p \leq 0.05$. The calculation of $\mathrm{IC}_{50}$ value i.e. the concentration of extract in $\mathrm{mg} / \mathrm{mL}$ used for scavenging $50 \%$ free radicals was determined from the regression equation. Correlation analysis was also done to determine the relationship between the phenolic 


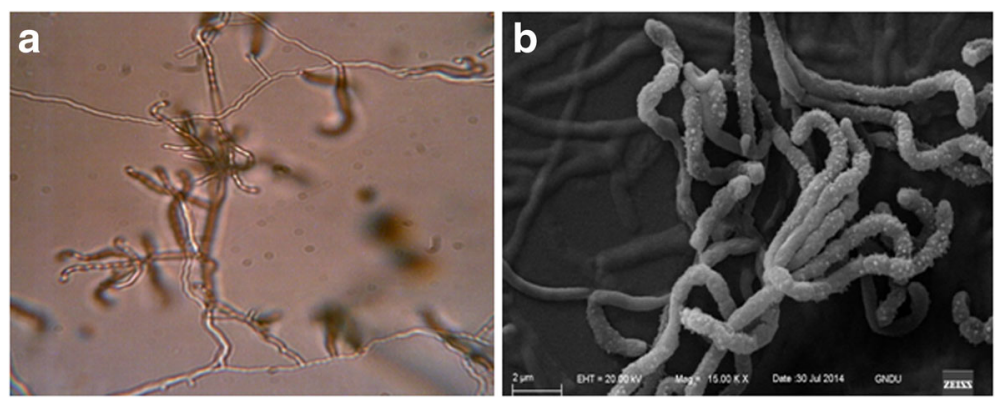

Fig. 1 (a) Light micrograph at 100X showing flexous spore chains on aerial mycelium of Streptomyces TES17 (b) Electron microscopic view of spores showing rough surface

content, total flavonoid content and the antioxidant capacity of the extract using SPSS.

\section{Results}

\section{Phenotypic analysis of strain S. cellulosae TES17}

The strain TES17 showed gray sporulation with cream color aerial mycelium, while the substrate mycelium was of dark brown color on SCNA medium. In light microscope (100X), flexuous sporophores with short chains were observed and placed in Rectus-Flexibilis (RF) group of Streptomyces (Fig. 1a). Micromorphological studies by SEM revealed the branched spore chains, bearing 7-12 cylindrical spores $(1.5-2.0 \mu \mathrm{m} \mathrm{X} 1.5 \mu \mathrm{m})$ having a rough surface (Fig. 1b). Culture characteristics of the strain are described in Table 1.

The culture grew well on all the ISP media except tryptone yeast agar (ISP 1). Pigmentation was not observed in any of the media. Strain TES17 did not produce melanin pigment on tyrosine agar (ISP 7). These cultural characteristics of strain TES17 were in line with the genus Streptomyces. The isolate could grow between $18{ }^{\circ} \mathrm{C}$ to $50{ }^{\circ} \mathrm{C}$ (optimum at $28{ }^{\circ} \mathrm{C}$ ), pH 5.0 to 12.0 (optimum at pH 7.0). It could tolerate $\mathrm{NaCl}$ concentration up to $2.5 \%$. The strain TES17 hydrolyzed starch, lipid, gelatin, and esculin but gave negative results for both indole production and MRVP test. In the enzymatic activity, it could produce industrially important enzymes such as cellulase, urease, $\beta$ galactosidase and citrase by degrading their respective substrates cellulose, urea, ortho-Nitrophenyl- $\beta$-galactoside (ONPG) and citrate. However, the strain could neither reduce nitrate nor produce $\mathrm{H}_{2} \mathrm{~S}$. Strain TES17 was able to utilize glucose, arabinose and malonate as sole carbon source, showed weak growth on medium containing xylose, rhamnose and cellobiose, but didn't utilize the raffinose and trehalose (Table 2).

\section{Phylogenetic and genomic analyses based on 16S rRNA sequencing}

The almost complete 16S rRNA gene sequence (1445 bp) of strain TES17 was determined and deposited in GenBank under accession no. KY511722. The sequence then compared with nucleotide sequences of other closely related taxa from the EzTaxon database. It showed $100 \%$ sequence similarity with Streptomyces cellulosae (AB184265). Further confirmation was done by constructing the phylogenetic trees using neighbor-joining, maximumparsimony and maximum likelihood algorithms (Fig. 2, Additional files 1 and 2). High boot strap value of 64 in neighbor-joining algorithm further validated that the strain TES17 belongs to S. cellulosae. Therefore, on the basis of phylogenetic analysis, the isolate TES17 was designated as S. cellulosae strain TES17.

\section{Antioxidant activity of Streptomyces TES17}

Further, antioxidant potential of $S$. cellulosae strain TES17 was investigated based on various in vitro

Table 1 Cultural characteristics of strain TES17 on various media

\begin{tabular}{|c|c|c|c|c|c|}
\hline Medium & Sporulation & S.M. ${ }^{a}$ & A.M. ${ }^{\text {b }}$ & Growth & Pigmentation \\
\hline ISP1 & - & Off white & - & Poor & - \\
\hline ISP2 & Dark gray & Dark brown & Light brown & Good & - \\
\hline ISP3 & Light gray & Dark brown & Light brown & Good & - \\
\hline ISP4 & Dark gray & Black & Cream & Good & - \\
\hline ISP5 & Gray & Pale yellow & Cream & Good & - \\
\hline ISP6 & - & Light brown & Light brown & Good & - \\
\hline ISP7 & Off white & Cream & Cream & Good & - \\
\hline
\end{tabular}

${ }^{\mathrm{a}}$ Substrate mycelium, ${ }^{\mathrm{b}}$ Aerial mycelium, $(-)=$ negative 
Table 2 Morphological, physiological and biochemical characteristics of Streptomyces TES17

\begin{tabular}{|c|c|}
\hline Properties & Result \\
\hline \multicolumn{2}{|l|}{ Morphological characteristics } \\
\hline Sporophore morphology & Rectus-flexibilis (RF) \\
\hline Aerial mycelium colour & Cream \\
\hline Substrate mycelium colour & Dark brown \\
\hline Spore surface & Rough \\
\hline \multicolumn{2}{|l|}{ Physiological characteristics } \\
\hline Production of melanoid pigment & - \\
\hline Temperature range for growth & $18^{\circ} \mathrm{C}$ to $50^{\circ} \mathrm{C}$ \\
\hline Optimum temperature for growth & $28^{\circ} \mathrm{C}$ \\
\hline $\mathrm{pH}$ range for growth & 5 to 12 \\
\hline Optimum pH for growth & 7.0 \\
\hline $\mathrm{NaCl}$ tolerance & Up to $2.5 \%$ \\
\hline \multicolumn{2}{|l|}{ Biochemical characteristics } \\
\hline Gelatin hydrolysis & + \\
\hline Starch hydrolysis & + \\
\hline Lipid hydrolysis & + \\
\hline Cellulase production & + \\
\hline Citrate utilization & + \\
\hline MRVP & - \\
\hline Indole production & - \\
\hline Urease production & + \\
\hline Nitrate reduction & - \\
\hline Esculin hydrolysis & + \\
\hline $\mathrm{H}_{2} \mathrm{~S}$ production & - \\
\hline ONPG ${ }^{a}$ hydrolysis & + \\
\hline Catalase test & + \\
\hline Oxidase test & + \\
\hline \multicolumn{2}{|l|}{ Utilization of: } \\
\hline Glucose & + \\
\hline Arabinose & + \\
\hline Xylose & $+/-$ \\
\hline Adonitol & - \\
\hline Rhamnose & $+/-$ \\
\hline Cellobiose & $+/-$ \\
\hline Lactose & - \\
\hline Malonate & + \\
\hline Raffinose & - \\
\hline Trehalose & - \\
\hline
\end{tabular}

Positive $=(+)$, negative $=(-)$, doubtful $=(+/-)$, ${ }^{\text {artho-Nitrophenyl- } \beta \text {-galactoside }}$

antioxidant assays including the DPPH radical scavenging, ABTS radical scavenging, superoxide radical scavenging assays, total reducing power assay and total antioxidant capacity (TAC) was determined by phosphomolybdenum assay. The results of these assays based upon percentage inhibition of free radicals are tabulated in Table 3. In this study, extract of TES17 exhibited significant dose dependent DPPH radical scavenging activity measured from $12.66 \pm 1.17$ to $78.47 \pm 0.23 \%(p \leq 0.05)$ at concentrations ranging from 0.5 to $5 \mathrm{mg} / \mathrm{mL}$, indicating the hydrogen donating ability of the TES17 extract to DPPH radicals. $\mathrm{IC}_{50}$ value i.e. $50 \%$ inhibition of $\mathrm{DPPH}$ radicals was achieved at concentration of $2.48 \mathrm{mg} / \mathrm{mL}$. ABTS assay also revealed the potential of TES17 extract by scavenging the ABTS radical cations measuring from $67.73 \pm 2.76$ to $91.08 \pm 0.98 \%(p \leq 0.05)$ at concentrations ranging from 0.5 to $5 \mathrm{mg} / \mathrm{mL}$. The TES17 extract was also tested for its scavenging capability against superoxide radicals $\left(\mathrm{O}_{2}^{\circ}\right)$. In this assay, conversion of highly water soluble Nitroblue Tetrazolium (NBT) salt into water soluble NBT diformazan dye takes place via reduction of superoxide radical. The rate of the reduction with $\mathrm{O}_{2}^{--}$is linearly related to the activity of xanthine oxidase (XO) which is inhibited by superoxide dismutase (SOD). The results showed significant activity measuring from $10.37 \pm 2.09$ to $82.08 \pm 0.93 \%(p \leq 0.05)$ at different doses ranging from 0.5 to $5 \mathrm{mg} / \mathrm{mL}$. Extract showed $50 \%$ inhibition i.e. $\mathrm{IC}_{50}$ at $2.41 \mathrm{mg} / \mathrm{mL}$.

Total antioxidant activity and total reducing power was expressed as mg Ascorbic Acid Equivalents (AAE)/ $100 \mathrm{mg}$ dry weight of extracts. The higher antioxidant capacity was indicated by the high absorbance at a particular wavelength. Molybdate ion and ferric ion reduction potential were found to be $76.93 \pm 0.76$ and $231.96 \pm 0.51 \mathrm{mg}$ AAE/100 mg dry weight of TES17 extract, respectively.

\section{Lipid peroxidation assay}

TES17 extract was also tested for in vivo effects on oxidative damage induced by free radicals on polyunsaturated fatty acids which results in the generation of mutagenic and toxic products, especially MDA. TES17 extract showed inhibition to lipid peroxidation as demonstrated by significant decrease in the relative percentage of MDA level (from 100 to 32.88\%). The percentage inhibition at all the tested concentrations (ranging from 0.5 to $5 \mathrm{mg} / \mathrm{mL}$ ) varied from $4.44 \pm$ 0.34 to $67.18 \pm 1.9 \%$ and shown as statistically significant at $p \leq 0.05$ (Table 4 ).

\section{Phenolic and flavonoid contents of TES17 extract}

In the calculation of TPC of the extract, the phenolic compounds in the extract undergo reaction with phosphomolybdic acid in the presence of Folin-Ciocalteau reagent and lead to the production of a blue coloured complex in alkaline medium which is directly correlated with high antioxidant activity. The TPC of TES17 extract was expressed as Gallic Acid Equivalents/100 mg of dry 


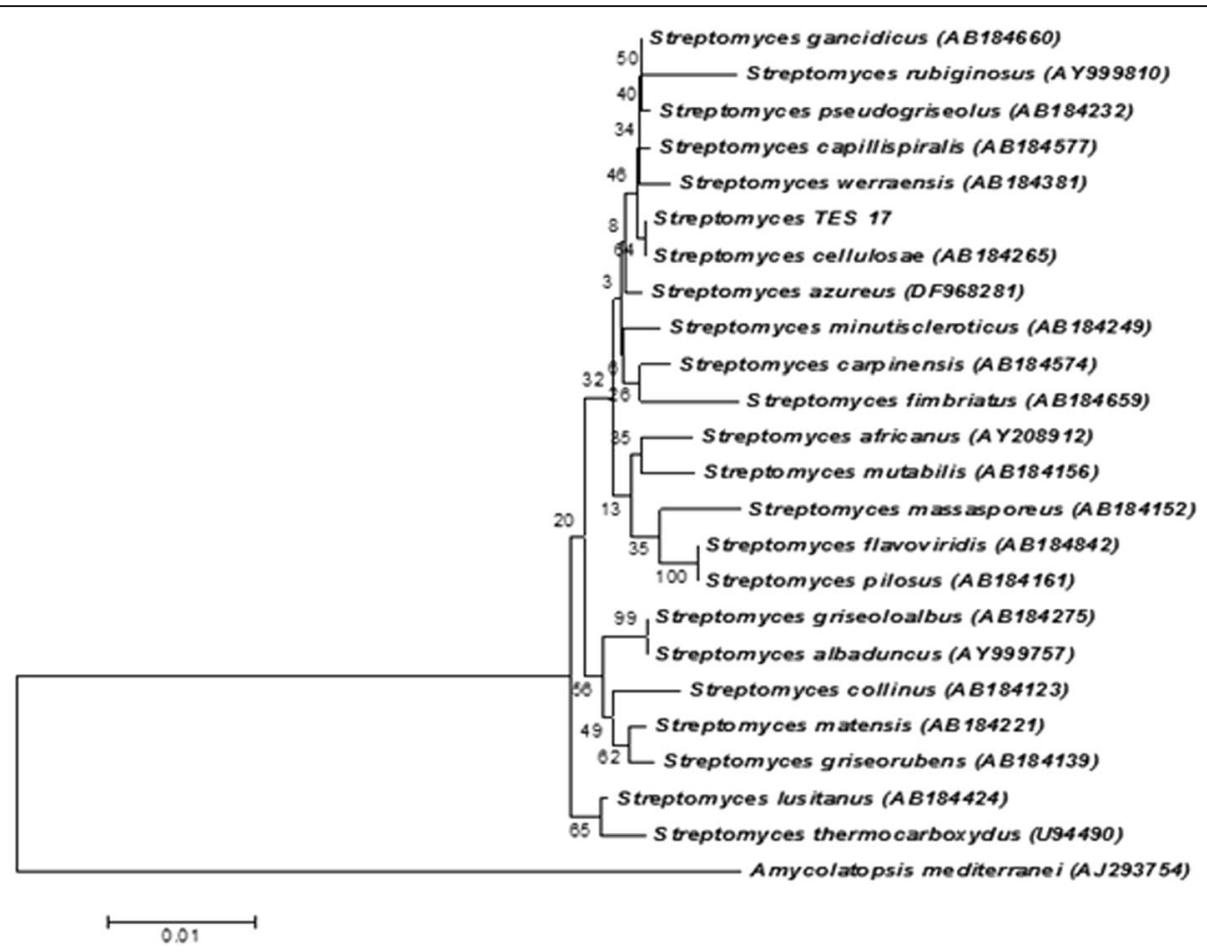

Fig. 2 Neighbor-joining algorithm based on nearly complete 16S rRNA gene sequences showing the position of Streptomyces TES17 amongst its phylogenetic neighbors. Bootstrap values (expressed as percentages of 1000 replications) are shown at the nodes. Amycolatopsis mediterranei (AJ293754.1) was used as an out group. GenBank accession numbers are given in parentheses

weight of extract which was accounted as $55 \mathrm{mg}$ GAE/ $100 \mathrm{mg}$ of extract. Along with phenolics, flavonoids also are the major part of secondary metabolites which were quantified using colorimetric assay. In this, aluminum chloride forms acid stable complexes with the C-4 keto group or either with the C-3 or C-5 hydroxyl group of flavones and flavonols. In addition, aluminum chloride forms acid-labile complexes with the orthodihydroxyl groups in the A- or B-ring of flavonoids, absorbed at $510 \mathrm{~nm}$. Total flavonoid content of TES17 extract was measured as $11.17 \pm 4.05 \mathrm{mg}$ rutin/100 $\mathrm{mg}$ of extract.

Table 3 The antioxidant activities demonstrated by TES17 extract in different antioxidant assays

\begin{tabular}{llll}
\hline $\begin{array}{l}\text { Concentration of TES17 } \\
\text { extract }(\mathrm{mg} / \mathrm{mL})\end{array}$ & Antioxidant activities & \\
\cline { 2 - 4 } & $\begin{array}{l}\text { DPPH radical } \\
\text { scavenging } \\
\text { activity (\%) }\end{array}$ & $\begin{array}{l}\text { ABTS radical } \\
\text { scavenging } \\
\text { activity (\%) }\end{array}$ & $\begin{array}{l}\text { Superoxide anion } \\
\text { scavenging } \\
\text { assay (\%) }\end{array}$ \\
\hline 0.5 & $12.66 \pm 1.17^{*}$ & $67.73 \pm 2.76^{*}$ & $10.37 \pm 2.09^{*}$ \\
1 & $34.55 \pm 0.14^{*}$ & $72.39 \pm 1.27^{*}$ & $27.50 \pm 0.77^{*}$ \\
2 & $48.88 \pm 2.12^{*}$ & $76.25 \pm 1.65^{*}$ & $52.88 \pm 1.04^{*}$ \\
3 & $64.91 \pm 1.58^{*}$ & $82.65 \pm 1.73^{*}$ & $68.02 \pm 0.72^{*}$ \\
4 & $69.86 \pm 2.48^{*}$ & $87.40 \pm 1.21^{*}$ & $75.65 \pm 0.94^{*}$ \\
5 & $78.47 \pm 0.23^{*}$ & $91.08 \pm 0.98^{*}$ & $82.08 \pm 0.93^{*}$ \\
\hline
\end{tabular}

*Statistically significant $(p \leq 0.05)$ when compared to control (without extract)
To assess the relationship between the antioxidant capacity using different antioxidant assays, TPC and TFC of TES17 extract, correlation analysis was performed. The perason's correlation coefficients between these variables are presented in Table 5 . The analysis clearly indicated that the highest correlation was found between ABTS radical scavenging activity, TPC and TFC of the extract with $r=0.995$ and 0.985 , respectively $(p \leq 0.01)$. The analysis also suggested that the antioxidant activity was largely contributed by the phenolic compounds, especially flavonoids present in the TES17 extract.

Table 4 Inhibition of lipid peroxidation and effect of TES17 extract on the MDA level in egg homogenate

\begin{tabular}{lll}
\hline $\begin{array}{l}\text { Concentration of TES17 } \\
\text { extract }(\mathrm{mg} / \mathrm{mL})\end{array}$ & $\begin{array}{l}\text { Percentage } \\
\text { inhibition }\end{array}$ & $\begin{array}{l}\text { Relative percentage } \\
\text { of MDA }\end{array}$ \\
\hline 0.5 & $4.44 \pm 0.34^{*}$ & $95.61^{*}$ \\
1 & $8.78 \pm 0.68^{*}$ & $91.21^{*}$ \\
2 & $15.64 \pm 2.36^{*}$ & $84.39^{*}$ \\
3 & $27.57 \pm 1.11^{*}$ & $72.42^{*}$ \\
4 & $52.48 \pm 0.11^{*}$ & $47.58^{*}$ \\
5 & $67.18 \pm 1.9^{*}$ & $32.88^{*}$ \\
\hline
\end{tabular}

All data are presented as the mean \pm SD $(n=3)$. * Denotes $p \leq 0.05$ between control sample (without extract) and TES17 extract treated sample 
Table 5 Pearson's correlation coefficients between TPC, TFC and antioxidant activities of TES17 extract

\begin{tabular}{lll}
\hline Antioxidant activities & $\begin{array}{l}\text { Total Phenolic } \\
\text { Content }\end{array}$ & $\begin{array}{l}\text { Total Flavonoid } \\
\text { Content }\end{array}$ \\
\hline DPPH radical scavenging activity & $r=0.978^{* *}$ & $r=0.945^{* *}$ \\
ABTS radical scavenging activity & $r=0.995^{* *}$ & $r=0.985^{* *}$ \\
Superoxide anion scavenging activity & $r=0.974^{* *}$ & $r=0.933^{* *}$ \\
Lipid peroxidation activity & $r=0.964^{* *}$ & $r=0.986^{* *}$ \\
\hline
\end{tabular}

${ }^{*}$ Correlation is significant at the $p \leq 0.001$ level

DNA protective effect against oxidative damage induced by $\mathrm{H}_{2} \mathrm{O}_{2}$ using DNA nicking assay

The DNA nicking assay revealed that TES17 extract protected the supercoiled DNA pBR322 from the destructive effects of hydroxyl radicals generated by Fenton's reagent. It was observed that supercoiled form of plasmid DNA (Form I; Lane 1) was degraded to single stranded and double stranded nicked and linear forms of DNA (Form II and III, respectively; Lane 2) due to hydroxyl radicals generated in Fenton's reaction mixture. However, addition of TES17 extract at different concentrations (from 2 to $10 \mu \mathrm{g} /$ well) to the reaction mixture minimized the hydroxyl radical mediated DNA damage i.e. conversion of supercoiled DNA (Form I) to the formation of single stranded nicked DNA (Form II) and double stranded nicked and linear DNA (Form III) as shown in lanes 4-8. Lane 3 shows the positive control rutin, which maintained the integrity of the DNA to the Form I (Fig. 3).

The densitometric analysis determined the percentage of DNA present in three forms. Figure 4 demonstrates that the amount of supercoiled DNA in the presence of TES17 extract and Fenton's reagent was found to be $38.2 \%(10 \mu \mathrm{g}), 31.82 \% \quad(8 \mu \mathrm{g}), 29.97 \%$ $(6 \mu \mathrm{g}), 26.89 \%(4 \mu \mathrm{g})$ and $26.38 \%(2 \mu \mathrm{g})$, indicating that the increasing concentration of extract protect the damaged DNA with higher intensity. The results were in comparison with the amount of supercoiled
DNA present in positive control (rutin + Fenton's reagent) with $36.54 \%$. In the presence of Fenton's reagent only, the amount of Form I was found to be $4.61 \%$ and simultaneously, Form II increased from $49.27 \%$ to $77.61 \%$ (Table 6 ).

\section{Cytotoxic activity of Streptomyces TES17 extract}

In addition, TES17 extract displayed cytotoxic activity against A549 lung cancer cell line with recording viability ranging from $25.3 \pm 1.52$ to $22.72 \pm 0.34 \%$ (Fig. 5a). A dose response pattern, evaluated using different doses, indicated that the TES17 extract was highly effective even at the lowest tested concentration $(30 \mu \mathrm{g} / \mathrm{mL})$ with $74.7 \pm 1.33 \%$ inhibition against cancer cell line and increased concentration didn't show any effect. Furthermore, it was also observed that there was significant difference ( $p \leq 0.05)$ between control and increasing concentration of the extract. As for the HEK-293 T (Human Embryonic Kidney normal cell line), TES17 extract displayed insignificant cytotoxic effect with $87.71 \pm 6.66$ to $85.41 \pm 3.14 \%$ viability of the tested cells at different concentrations of the extract (Fig. 5b).

\section{Chemical profiling of Streptomyces TES17 extract using UPLC analysis}

To determine the phenolic compounds that may be responsible for its antioxidant, DNA protective and cytotoxic properties, TES17 extract was subjected to UPLC analysis. The results of UPLC analysis revealed that it contained nine compounds (Table 7 and Additional file 3): Gallic acid (1), Catechin (2), Epicatechin (3), Caffeic acid (4), Umbelliferone (5), Coumaric acid (6), Ellagic acid (7), Quercetin (8) and Kaempferol (9) with chemical structures shown in Fig. 6. It was clearly analysed that phenolic acids and flavanoids were the main classes of phenolic compounds present in the extract.

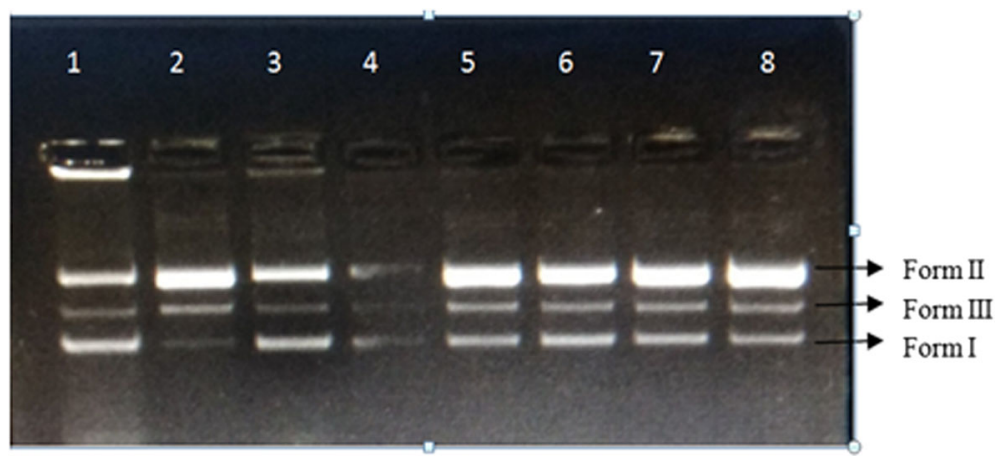

Fig. 3 DNA Nicking assay revealing protective potential of TES17 extract against free radicals generated by Fenton's reagent. Lane 1: Negative control (only DNA); Lane 2: Fenton's reagent; Lane 3: Positive control (rutin, $10 \mu \mathrm{g}$ ); Lane 4-8: Fenton's reagent +2, 4, 6, 8 and $10 \mu \mathrm{g}$ of TES17 extract; Form I = Supercoiled; Form $\|$ = Linear; Form $I \|$ = Single strand nicked DNA 


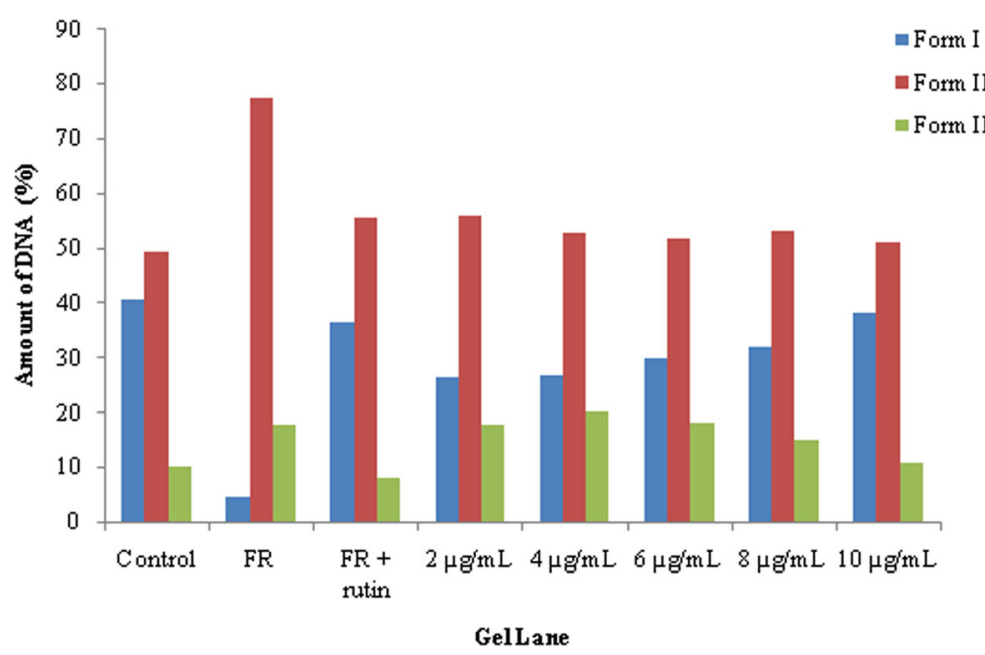

Fig. 4 Densitometric analysis of DNA protective effects of TES17 extract in the presence of hydroxyl radicals generated in DNA nicking assay. Form I- supercoiled DNA, Form II- single stranded nicked DNA, Form III- double standed nicked and linear DNA

\section{Discussion}

The 'rhizosphere', narrow and specific zone forms unique microhabitat from a bulk of the soil in terms of high nutrient availability, optimum $\mathrm{pH}$ and input of organic materials derived from root exudates [48]. These conditions favor the abundance of diverse microbial community in the rhizosphere. In well-studied rhizosphere, root exudates play an important role in enhanced biomass and activity of microorganisms $[22,49]$. The complex interactions between plants and microorganisms in the rhizosphere for carbon sequestration, ecosystem functioning and nutrient cycling, lead to the production of novel bioactive metabolites [50]. Among microorganisms, Streptomyces, a largest known genus of actinobacteria which commonly inhabit rhizosphere soil, has been greatly explored as producer of a wide variety of unique metabolites with interesting biological activities [20, 51]. Therefore, it is an efficient approach to explore Streptomyces spp. from such environment for the discovery of novel bioactive compounds.

In the present study, Streptomyces strain TES17 isolated from rhizosphere of tea (Camellia sinensis) was characterized through the polyphasic approach which included morphological, physiological, biochemical molecular characterization, and phylogenetic analysis. It formed branched short spore chains having a rough surface as observed via SEM studies. The strain was capable to survive under unfeasible growth conditions because it could tolerate $\mathrm{NaCl}$ concentration of $2.5 \%$, temperature up to $50{ }^{\circ} \mathrm{C}$ and $\mathrm{pH} 12.0$. Furthermore, strain TES17 also could have the potential to gain attention in industrial sector due to the production of industrially important enzymes such as cellulase, amylase, and $\beta$-galactosidase. The type and quantity of secondary metabolites are greatly influenced by the availability of substrates given during the growth [52]. The results revealed that strain was capable to utilize different carbon sources such as glucose, arabinose, malonate, xylose, rhamnose, and cellobiose. Phylogenetic analysis based on 16S rRNA gene sequences showed that strain TES17 is closely related to Streptomyces cellulosae (AB184265) as they showed $100 \%$ sequence similarity and formed a distinct clade at the bootstrap value of $64 \%$ which was significantly higher than the threshold value of $50 \%$. However, phenotypically the strain TES17 is different from reference strain Streptomyces cellulosae (AB184265) in terms of having rough spore surface [53]. Overall, the strain TES17 could belong to same species as $S$. cellulosae (AB184265) based on 16S rRNA sequencing. To the best of our knowledge, S. cellulosae strain TES17 has not been reported earlier for the antioxidant, DNA damage protective and anticancer activities.

Table 6 Densitometric analysis of different forms of DNA (in percentage) after treatment with varying concentrations of TES17 extract

\begin{tabular}{lllllllll}
\hline Form & Control (only DNA) & ${ }^{\mathrm{a}} \mathrm{FR}$ & Rutin $(10 \mu \mathrm{g})+\mathrm{FR}$ & \multicolumn{5}{l}{ Concentration of TES17 extract } \\
\cline { 5 - 8 } & & & & $2 \mu \mathrm{g}$ & $4 \mu \mathrm{g}$ & $6 \mu \mathrm{g}$ & $8 \mu \mathrm{g}$ \\
\hline Form I & 40.798 & 4.605 & 36.54 & 26.378 & 26.89 & 29.977 & 31.823 & 38.203 \\
Form II & 49.274 & 77.614 & 55.609 & 56.043 & 52.988 & 51.871 & 53.076 & 50.987 \\
Form III & 9.928 & 17.781 & 7.845 & 17.578 & 20.122 & 18.151 & 15.101 & 10.81 \\
\hline
\end{tabular}

${ }_{\mathrm{a}}^{\mathrm{F} R}=$ Fenton's Reagent, Form I - supercoiled DNA, Form II - single stranded nicked DNA, Form III - double standed nicked and linear DNA 

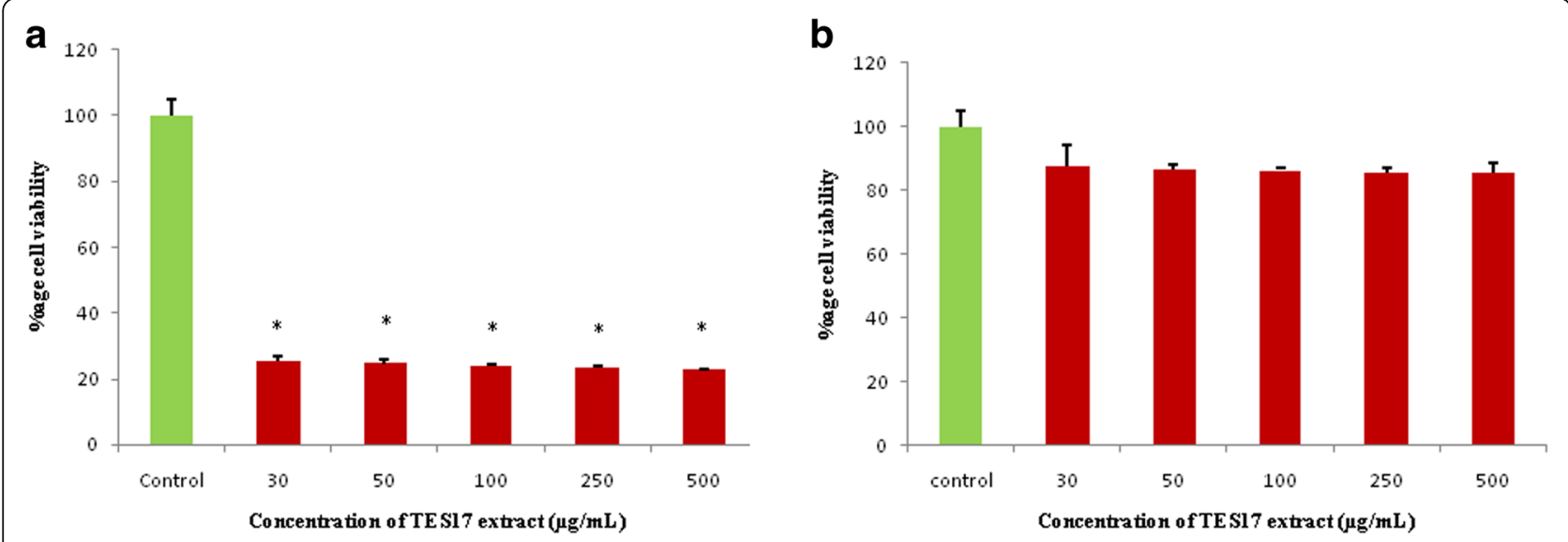

Fig. 5 Effect of TES17 extract against (a) cancer cell line and (b) normal cell line. The viability of control cells (without TES17 extract) was defined as $100 \%$. Data shown are mean \pm SD $(n=3)$. ${ }^{*}$ Denotes $p \leq 0.05$ between control cells and treated cells

Oxidative stress and other neurodegenerative diseases are associated with accumulation of free radicals or ROS $[54,55]$. The process of oxidation may occur via different types of radicals which have different types of reaction mechanisms based on their interaction with surrounding molecules such as electron donation, reducing radicals, and electron acceptance $[55,56]$. Hence, to assess the overall antioxidant potential of the extract, a total of six assays which elicit different mechanism of actions were performed. These assays demonstrated that the TES17 extract exhibited DPPH radical scavenging activity, ABTS radical scavenging activity, superoxide anion scavenging activity, reducing power of ferric ions and molybdate ions and ability to inhibit lipid peroxidation.

Simplest and robust methods to screen antioxidant activity are DPPH and ABTS assays. These assays involve stable free DPPH and ABTS + radicals. Hydrogen donating potential of antioxidants is responsible for their effects on DPPH and ABTS radicals. The transfer of hydrogen atom or electron by the antioxidant molecule to the DPPH and ABTS radical leads to the decolorization of violet and bluish-green color, respectively [57]. Besides the hydrogen donating ability, TES17 extract also has the tendency to scavenge the superoxide anion radical $\left(\mathrm{O}_{2}^{\circ}\right)$. Excessive generation of $\mathrm{O}_{2}^{--}$(directly or indirectly) involves in the formation of other highly reactive hydrogen peroxides $\left(\mathrm{H}_{2} \mathrm{O}_{2}\right)$, notorious hydroxyl radicals $\left(\mathrm{OH}^{*}\right)$, peroxynitrite $\left(\mathrm{ONOO}^{-}\right)$or singlet oxygen species during the process of aging and pathological events which ultimately contribute to oxidative stress and carcinogenesis [58]. Thus, the increased production rate of $\mathrm{O}_{2}^{--}$overwhelms the capacity of superoxide dismutase enzyme of an internal defense system. So, the need to control $\mathrm{O}_{2}^{\circ-}$ production to prevent oxidative stress is of great importance [59].

Some of the assays including total reducing power, total antioxidant activity, total phenol content and total flavonoid content are the direct measure of presence of the phenolic compounds. Total reducing power of extract was determined by measuring the reduction of potassium ferricyanide $\left(\mathrm{Fe}^{3+}\right)$ to potassium ferrocyanide $\left(\mathrm{Fe}^{2+}\right)$ which further undergoes reaction with ferric chloride to produce ferric ferrous complex (which has intense blue color). The higher reducing potential of the

Table 7 Phenolic compounds identified in TES17 extract

\begin{tabular}{|c|c|c|c|c|c|}
\hline Sr. No. & Phenoic Compounds & Retention Time (min) & Concentration (mg/L) & Molecular Formula & Molecular Weight (MW) \\
\hline 1 & Gallic acid & 2.579 & 127.735 & $\mathrm{C}_{7} \mathrm{H}_{6} \mathrm{O}_{5}$ & 170.12 \\
\hline 2 & Catechin & 3.912 & 804.940 & $\mathrm{C}_{15} \mathrm{H}_{14} \mathrm{O}_{6}$ & 290.27 \\
\hline 3 & Epicatechin & 6.244 & 46.223 & $\mathrm{C}_{15} \mathrm{H}_{14} \mathrm{O}_{6}$ & 290.27 \\
\hline 4 & Caffeic acid & 6.951 & 39.985 & $\mathrm{C}_{9} \mathrm{H}_{8} \mathrm{O}_{4}$ & 180.16 \\
\hline 5 & Umbelliferone & 9.749 & 19.264 & $\mathrm{C}_{9} \mathrm{H}_{6} \mathrm{O}_{3}$ & 162.14 \\
\hline 6 & Coumaric acid & 10.290 & 0.652 & $\mathrm{C}_{9} \mathrm{H}_{8} \mathrm{O}_{3}$ & 164.16 \\
\hline 7 & Ellagic acid & 15.668 & 26.972 & $\mathrm{C}_{14} \mathrm{H}_{6} \mathrm{O}_{8}$ & 302.19 \\
\hline 8 & Quercetin & 16.426 & 12.485 & $\mathrm{C}_{15} \mathrm{H}_{10} \mathrm{O}_{7}$ & 302.23 \\
\hline 9 & Kaempferol & 17.554 & 8.943 & $\mathrm{C}_{15} \mathrm{H}_{10} \mathrm{O}_{6}$ & 286.23 \\
\hline
\end{tabular}


<smiles>O=C(O)c1cc(O)c(O)c(O)c1</smiles>

(1)<smiles>O=C(O)/C=C/c1ccc(O)c(O)c1</smiles>

(4)

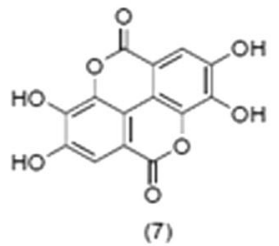<smiles>Oc1cc(O)c2c(c1)OC(c1ccc(O)c(O)c1)C(O)C2</smiles>

(2)<smiles>O=c1ccc2ccc(O)cc2o1</smiles>

(5)<smiles>O=c1c(O)c(-c2ccc(O)c(O)c2)oc2cc(O)cc(O)c12</smiles>

(8)<smiles>Oc1cc(O)c2c(c1)OC(c1ccc(O)c(O)c1)C(O)C2</smiles>

(3)<smiles>O=C(O)/C=C/c1ccc(O)cc1</smiles>

(6)

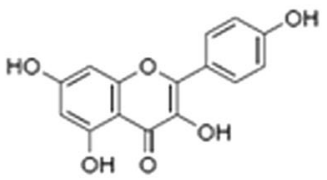

(9)

Fig. 6 Chemical structures of phenolic compounds detected in TES17 extract

extract was indicated by the increase in absorbance. Similarly, in molybdate ion reduction assay antioxidant compound reduces Mo (VI) to Mo (V) that results in the formation of green colored phosphate/ Mo (V) complex at acidic $\mathrm{pH}$ that determines the process of donation of electrons $[42,60]$.

The targets of ROS are mainly proteins, DNA, RNA molecules, sugars and lipids [61]. Lipids having many numbers of $\mathrm{C}=\mathrm{C}$ bonds undergo easier oxidative deterioration resulting in the formation of monounsaturated (MUFA) and saturated fatty acids (SFA), more resistant to radicals than polyunsaturated fatty acids (PUFA). The process of lipid peroxidation is initiated by an attack towards a fatty acid's side chain by a hydroxyl radical $\left(\mathrm{OH}^{*}\right)$ produced by the interaction between hydrogen peroxide and iron metal ions present in Fenton reaction. This process abstracted a hydrogen atom from a methylene carbon which further undergoes molecular rearrangements and forms a peroxyl radical. The latter facilitates the production of the carcinogenic and mutagenic product MDA [55]. The reduction in MDA level by inhibiting the ferryl-perferryl complex and quenching the $\mathrm{OH}^{*}$ confirmed the significant role of TES17 extract in inhibiting lipid peroxidation [62].

To further support the antioxidant potential, this study demonstrated the DNA protective effect of TES17 extract using oxidative stress induced DNA damage model. In DNA nicking assay, $\mathrm{O}_{2}^{--}$radical is produced by the autoxidation of $\mathrm{Fe}$ (II) which further generates $\mathrm{OH}^{*}$ by a rapid reaction of $\mathrm{H}_{2} \mathrm{O}_{2}$ in the presence of ascorbic acid as catalyst at $\mathrm{pH}$ 7.4. Ascorbate plays the role of reducing $\mathrm{Fe}$ (III) to Fe (II) making Fenton reaction to take place $[63,64]$. A decrease in the single stranded or double stranded nicked (Form II) and linear forms of DNA (Form III), and simultaneous increase in the native supercoiled form (Form I) in the presence of extract confirmed protective effect of TES17 against ROS induced DNA damage.

Oxidative stress ultimately initiates cancer progression by various modifications in the biological molecules which eventually lead to increased mutation rate [65]. Various antioxidant assays revealed that the extract TES17 produced such bioactive compounds which could be further used as chemopreventive drugs to reduce cancer. An ideal chemotherapeutic drug should have high specificity i.e. able to differentiate cancer and normal cells. However, many of the drugs in use are still lacking in the drug specificity as they kill both cancer as well as normal cells [66, 67]. This study investigated the specificity of TES17 extract which revealed that the extract was highly toxic to A549 lung cancer cell line $(25.3 \pm 1.52$ to $22.72 \pm$ $0.34 \%$ viable cells) as compared to normal cell line $(87.71 \pm 6.66$ to $85.41 \pm 3.14 \%$ viable cells) at the different tested concentrations. These key findings could provide useful information for future development of S. cellulosae strain TES17 as the producer strain of anticancer drugs. 
The correlation studies between the antioxidant assays, the total phenolics and favonoids in the TES17 extract suggested that phenolic compounds (both phenolic acids and flavonoids) made a significant contribution to the antioxidant potential of Streptomyces TES17. Further confirmation of phenolic compounds in the TES17 extract was done using HPLC analysis which is a powerful analytical tool and widely used for the detection of phenolic compounds based on the particular retention time [68]. Phenolic acids are derivatives of hydroxybenzoic acids and hydroxycinnamic acids such as gallic acid, caffeic acid and coumaric acid [69]. Second class of phenolic compounds are flavonoids which are mainly characterized as containing two phenolic rings (Ring $\mathrm{A}$ and Ring $\mathrm{B}$ ) linked by another oxygenated heterocycle which is three carbon bridge (Ring C), forming a common diphenylpropane (C6-C3-C6) skeleton structure. Based upon the saturation level of the $\mathrm{C}$ ring, flavonoids are classified into different subclasses viz. flavonols, flavanols, anthocyanins, isoflavonoids, flavanones and flavones. Individual compounds within a subclass differ in the substitution pattern of hydroxyl groups present in the A and B rings that influence the free radical-scavenging properties of the phenolic compounds [70]. Some of the most important flavonoids are catechin, rutin, quercetin and kaempferol. Both phenolic acids and other flavonoids act as antioxidants by chelating the ions and scavenging he free radicals particularly, superoxide $\left(\mathrm{O}_{2}^{\bullet-}\right)$, peroxyl and hydroxyl radicals $\left(\mathrm{OH}^{\bullet}\right)$ and hence inhibit both DNA damage and lipid peroxidation, which can cause membrane damage.

UPLC analysis of extract of $S$. cellulosae strain TES17, isolated from tea rhizosphere, revealed that among nine phenolic compounds [viz. catechin, epicatechin, quercetin and kaempferol (flavonoids), gallic acid, caffeic acid and coumaric acid (phenolic acids) and umbelliferone (coumarine)], catechins were the principal phenolic compounds. Catechins are reported to be the main phenolic compounds responsible for antioxidant activity of the tea. The principal catechins present in tea leaves are epigallocatechin gallate (EGCG), epigallocatechin (EGC), epicatechin gallate (ECG), gallocatechin (GC), epicatechin (EC), and catechin [28, 71]. These results suggest that there could be gene transfer between tea plant and rhizospheric microflora which further elaborate the potential of Streptomyces TES17 in search of phenolic compounds with interesting bioactivities.

\section{Conclusions}

The present study showed the true antioxidant potential of $S$. cellulosae strain TES17 as it was able to scavenge several free radicals including DPPH, ABTS and superoxide anions; inhibit lipid peroxidation and protect DNA from the damage caused by oxidative stress. The biopharmaceutical importance of TES17 extract was further established by the cytotoxic activity against cancer cell line with high specificity. UPLC analysis demonstrated that the catechins were the major phenolic compounds in the extract responsible for various bioactivities. Therefore, the findings of the present study indicate that S. cellulosae strain TES17 holds promise for large scale production of free radical scavenging agents which can be developed as chemotherapeutic drugs used in the intervention of oxidative stress-mediated diseases.

\section{Additional files}

Additional file 1: Maximum-parsimony phylogenetic tree based on $16 \mathrm{~S}$ rRNA gene sequences of Streptomyces strains showing the position of isolate Streptomyces TES17. Bootstrap values (expressed as percentages of 1000 replications) are shown at the nodes. (DOCX $16 \mathrm{~kb}$ )

Additional file 2: Maximum-likelihood phylogenetic tree based on $16 \mathrm{~S}$ rRNA gene sequences of Streptomyces strains showing the position of isolate Streptomyces TES17. Bootstrap values (expressed as percentages of 1000 replications) are shown at the nodes. (DOCX $15 \mathrm{~kb}$ )

Additional file 3: UPLC analyses of TES17 extract showing nine different phenolic compounds based on particular retention time. (DOCX 167 kb)

\section{Abbreviations}

ABTS: 2,2'- azino-bis (3-ethylbenzothiazoline-6-sulfonic acid); DPPH: 2,2diphenyl-1-picrylhydrazyl; MTT: 3-(4,5-Dimethylthiazol-2yl)-2,5-Diphenyl Tetrazolium Bromide; ROS: Reactive oxygen species; SCNA: Starch casein nitrate agar medium; TFC: Total flavonoid content; TPC: Total phenolic content; UPLC: Ultra high pressure liquid chromatography

\section{Acknowledgements}

We duly acknowledge University Grants Commission (UGC), New Delhi for providing funds to accomplish this work.

\section{Funding}

This work was financially supported by the University Grants Commission (UGC), New Delhi and RR also acknowledges the grant of fellowship under UPE (University with Potential for Excellence) scheme of University Grants Commission, New Delhi, India vide letter no. 10819/Estt./A-2 Dated 27/05/13.

\section{Availability of data and materials}

All the data and materials have been provided in main manuscript.

\section{Authors' contributions}

RR was involved in the planning and execution of the research work; analysis and interpretation of the data; manuscript writing following the suggestions of research supervisor. SA and JK analyzed and interpreted the data related to cytotoxic activity using cancer and normal cell lines and drafted related content of the manuscript. RM as research supervisor of RR was involved in planning of research work; analysis and interpretation of data; drafting as well as critical editing of the manuscript for intellectual subject matter. All the authors approved the final version of the manuscript for publication and agreed to be accountable for all aspects of the work in ensuring that questions related to the accuracy or integrity of any part of the work are appropriately investigated and resolved.

Ethics approval and consent to participate Not applicable

\section{Consent for publication}

Not applicable

Competing interests

The authors declare that they have no competing interests. 


\section{Publisher's Note}

Springer Nature remains neutral with regard to jurisdictional claims in published maps and institutional affiliations.

\section{Author details}

'Department of Microbiology, Guru Nanak Dev University, Amritsar, Punjab 143005, India. ${ }^{2}$ Department of Botanical and Environmental Sciences, Guru Nanak Dev University, Amritsar, Punjab 143005, India.

Received: 6 October 2017 Accepted: 2 March 2018

Published online: 09 March 2018

\section{References}

1. Liu Y, Fiskum G, Schubert D. Generation of reactive oxygen species by the mitochondrial electron transport chain. J Neurochem. 2002;80:780-7.

2. Hancock JT, Desikan R, Neill SJ. Role of reactive oxygen species in cell signaling pathways. Biochem Soc Trans. 2001;29:345-50.

3. Tan LT-H, Chan K-G, Khan TM, Bukhari SI, Saokaew S, Duangjai A, et al. Streptomyces sp. MUM212 as a source of antioxidants with radical scavenging and metal chelating properties. Front Pharmacol. 2017;8:276.

4. Floyd RA, Hensley K. Oxidative stress in brain aging: implications for therapeutics of neurodegenerative diseases. Neurobiol Aging. 2002;23:795-807.

5. Giacco F, Brownlee M. Oxidative stress and diabetic complications. Circ Res. 2010;107:1058-70.

6. Farooqui T, Farooqui AA. Aging: an important factor for the pathogenesis of neurodegenerative diseases. Mech Ageing Dev. 2009;130:203-15.

7. Fearon IM, Faux SP. Oxidative stress and cardiovascular disease: novel tools give (free) radical insight. J Mol Cell Cardiol. 2009:47:372-81.

8. Dizdaroglu M. Oxidatively induced DNA damage and its repair in cancer Mutat Res Rev Mutat Res. 2015;763:212-45.

9. Apak R, Özyürek M, Güçlü K, Çapanoğlu E. Antioxidant activity/capacity measurement. 2. Hydrogen atom transfer (HAT)-based, mixed-mode (electron transfer (ET)/HAT), and lipid peroxidation assays. Agric Food Chem. 2016;64:1028-45.

10. Kumar PS, Al-Dhabi NA, Duraipandiyan V, Balachandran C, Kumar PP, Ignacimuthu S. In vitro antimicrobial, antioxidant and cytotoxic properties of Streptomyces lavendulae strain SCA5. BMC Microbiol. 2014;14:291.

11. Rechner AR, Kuhnle G, Bremmer P, Hubbard GP, Moore KP, Rice-Evans CA. The metabolic fate of dietary polyphenols in humans. Free Radic Biol Med. 2002;33:220-35.

12. Law JW-F, Ser H-L, Duangjai A, Saokaew S, Bukhari SI, Khan TM, et al. Streptomyces colonosanans sp. nov., a novel Actinobacterium isolated from Malaysia mangrove soil exhibiting Antioxidative activity and cytotoxic potential against human colon cancer cell lines. Front Microbiol. 2017;8:877.

13. Zhang H, Tsao R. Dietary polyphenols, oxidative stress and antioxidant and anti-inflammatory effects. Curr Opin Food Sci. 2016;8:33-42.

14. Njateng GSS, Du Z, Gatsing D, Mouokeu RS, Liu Y, Zang HX, et al. Antibacterial and antioxidant properties of crude extract, fractions and compounds from the stem bark of Polyscias fulva Hiern (Araliaceae). BMC Complement Altern Med. 2017:17:99.

15. Bush $\mathrm{K}$, Macielag M. New approaches in the treatment of bacterial infections. Curr Opin Chem Biol. 2000;4:433-9.

16. Chin Y-W, Balunas MJ, Chai HB, Kinghorn AD. Drug discovery from natural sources. AAPS J. 2006:8:239-53.

17. Ikeda H, Ishikawa J, Hanamato A, Shinose M, Kikuchi H, Shiba T, et al. Complete genome sequence and comparative analysis of the industrial microorganism Stretomyces avermitilis. Nat Biotechnol. 2003;21:526-31.

18. Demain AL, Sanchez S. Microbial drug discovery: 80 years of progress. J Antibiot. 2009;62:5-16.

19. Schatz A, Waksman SE. Effect of streptomycin and other antibiotic substances upon Mycobacterium tuberculosis and related organisms. Proc Soc Exp Biol Med. 1944;57:244-8.

20. Hopwood DA. Streptomyces in nature and medicine: the antibiotic makers. NewYork: Oxford University Press; 2007.

21. Manivasagan P, Venkatesan J, Sivakumar K, Kim SK. Pharmaceutically active secondary metabolites of marine actinobacteria. Microbiol Res. 2014;169: 262-78.

22. Raaijmakers JM, Paulitz TC, Steinberg C, Alabouvette C, Moënne-Loccoz Y. The rhizosphere: a playground and battlefield for soilborne pathogens and beneficial microorganisms. Plant Soil. 2009;321:341-61.
23. Yamamura H, Ashizawa H, Hamada M, Hosoyama A, Komaki H, Otoguro M, et al. Streptomyces hokutonensis sp. nov., a novel actinomycete isolated from the strawberry root rhizosphere. J Antibiot. 2014;67:465-70.

24. Guo K, Fang T, Wang J, Wu AA, Wang Y, Jiang J, et al. Two new spirooxindole alkaloids from rhizosphere strain Streptomyces sp. xzqh-9. Bioorg Med Chem Lett. 2014;24:4995-8.

25. Nguyen TM, Kim J. Streptomyces bambusae sp. nov., showing antifungal and antibacterial activities, isolated from bamboo (Bambuseae) rhizosphere soil using a modified culture method. Curr Microbiol. 2015;71:658-68.

26. Camargo LEA, Pedroso LS, Vendrame SC, Mainardes RM, Khalil NM. Antioxidant and antifungal activities of Camellia sinensis (L.) Kuntze leaves obtained by different forms of production. Braz J Biol. 2016;76:428-34.

27. Graham HN. Green tea composition, consumption, and polyphenol chemistry. Prev Med. 1992;21:334-50.

28. Chan EWC, Lim YY, Chew YL. Antioxidant activity of Camellia sinensis leaves and tea from a lowland plantation in Malaysia. Food Chem. 2007;102:1214-22.

29. Saito T, Miyata G. The nutraceutical benefit. Part I: green tea. Nutr. 2000;16:315-7.

30. Sharma D, Kaur T, Chadha BS, Manhas RK. Antimicrobial activity of actinomycetes against multidrug resistant Staphylococcus aureus, E. coli and various other pathogens. Trop J Pharm Res. 2011;10:801-8.

31. Sharma D, Mayilraj S, Manhas RK. Streptomyces amritsarensis sp. nov., exhibiting broad-spectrum antimicrobial activity. Antonie Van Leeuwenhoek. 2014;105: 943-9.

32. Shirling EB, Gotllieb D. Methods for characterization of streptomycetes sp. Int J Syst Bacteriol. 1966;16:313-40.

33. Cowan ST, Steel KJ. Manual for the identification of medical bacteria. London: Cambridge University Press; 1965.

34. Holding AJ, Collee JG. Routine biochemical tests. Methods Microbiol. 1971; 6A:1-31.

35. Lanyi B. Classical and rapid identification methods for medically important bacteria. Methods Microbiol. 1987;19:1-67.

36. Marmur JA. Procedure for the isolation of deoxyribonucleic acid from microorganisms. J Mol Biol. 1961;3:208-18.

37. Chun J, Lee JH, Jung Y, Kim M, Kim S, Kim BK, et al. EzTaxon: a web-based tool for the identification of prokaryotes based on 16S ribosomal RNA gene sequences. Int J Syst Evol Microbiol. 2007;57:2259-61.

38. Felsenstein J. Confidence limits on phylogenies: an approach using the bootstrap. Evolution. 1985;39:783-91.

39. Tamura K, Stecher G, Peterson D, Filipski A, Kumar S. MEGA6: molecular evolutionary genetics analysis version 6.0. Mol Biol Evol. 2013;28:2731-9.

40. Re R, Pellegrini N, Proteggente A, Pannala A, Yang M, Rice-Evans C. Antioxidant activity applying an improved ABTS radical cation decolorization assay. Free Radic Biol Med. 1999;26:1231-7.

41. Nishikimi M, Rao NA, Yagi K. The occurrence of superoxide anion in the reaction of reduced phenazine methosulfate and molecular oxygen. Biochem Biophys Res Comm. 1972;46:849-54.

42. Prieto P, Pineda M, Aguilar M. Spectrophotometric quantitation of antioxidant capacity through the formation of a phosphomolybdenum complex: specific application to the determination of vitamin E. Anal Biochem. 1999;269:337-41.

43. Oktay M, Gülçin I, Küfrevioğlu Öl. Determination of in vitro antioxidant activity of fennel (Foeniculum vulgare) seed extracts. Lebebsm Wiss Technol. 2003;36:263-71.

44. Dasgupta N, De B. Antioxidant activity of Piper betle L. leaf extract in vitro. Food Chem. 2004;88:219-24.

45. Yu L, Haley S, Perret J, Harris M, Wilson J, Qian M. Free radical scavenging properties of wheat extracts. J Agric Food Chem. 2002;50:1619-24.

46. Lee JC, Kim HR, Kim J, Jang YS. Antioxidant property of an ethanol extract of the stem of Opuntia ficus-indica var. saboten. J Agric Food Chem. 2002;50: 6490-6.

47. Mossman T. Rapid calorimetric assay for cellular growth and survival: application to proliferation and cytotoxic assays. J Immunol Methods. 1983;65:55-63.

48. Berg G, Smalla K. Plant species and soil type cooperatively shape the structure and function of microbial communities in the rhizosphere. FEMS Microbiol Ecol. 2009:68:1-13.

49. Bais HP, Weir TL, Perry LG, Gilroy S, Vivanco JM. The role of root exudates in rhizosphere interactions with plants and other organisms. Annu Rev Plant Biol. 2006;57:233-66.

50. Singh BK, Millard P, Whiteley AS, Murrell JC. Unravelling rhizosphere-microbia interactions: opportunities and limitations. Trends Microbiol. 2004;12:386-93.

51. Bonaldi M, Chen X, Kunova A, Pizzatti C, Saracchi M, Cortesi P. Colonization of lettuce rhizosphere and roots by tagged Streptomyces. Front Microbiol. 2015;6:25. 
52. Ser H-L, Law JW-F, Chaiyakunapruk N, Jacob SA, Palanisamy UD, Chan K-G, et al. Fermentation conditions that affect clavulanic acid production in Streptomyces clavuligerus: a systematic review. Front Microbiol. 2016;7:522.

53. Shirling EB, Gottlieb D. Cooperative description of type cultures of Streptomyces. IV. Species descriptions from the second, third and fourth studies. Int I Syst Bacteriol. 1969;19:391-512.

54. Halliwell B, Gutteridge JMC. Free radicals in biology and medicine. New York: Oxford University Press; 2007.

55. Carocho M, Ferreira IC. A review on antioxidants, prooxidants and related controversy: natural and synthetic compounds, screening and analysis methodologies and future perspectives. Food Chem Toxicol. 2013;51:15-25.

56. Slater TF. Free-radical mechanisms in tissue injury. Biochem J. 1984;222:1-15.

57. Deora SL, Khadabadi SS, Baviskar BA, Khangenbam RA, Koli US, Daga NP, et al. In vitro antioxidant activity and phenolic content of Croton caudatum. Int J ChemTech Res. 2009:1:174-6.

58. Meyer AS, Isaksen A. Application of enzymes as food antioxidants. Trends Food Sci Technol. 1995;6:300-4.

59. Sharma P, Jha AB, Dubey RS, Pessarakli M. Reactive oxygen species, oxidative damage, and antioxidative defense mechanism in plants under stressful conditions. J Bot. 2012;1:26.

60. Dorman HJD, Kosar M, Kahlos K, Holm Y, Hiltunen R. Antioxidant properties and composition of aqueous extracts from Mentha species, hybrids, varieties and cultivars. J Agric Food Chem. 2003;51:4563-9.

61. Lu J, Lin PH, Yao Q, Chen C. Chemical and molecular mechanisms of antioxidants: experimental approaches and model systems. J Cell Mod Med. 2010:14:840-60.

62. Nagulendran KR, Velavan $\mathrm{S}$, Mahesh R, Begum VH. In vitro antioxidant activity and total poly phenolic content of Cypreus rotundus rhizomes. J Chem. 2007:4:440-9.

63. Dizdaroglu $M$, Jaruga $P$, Birincioglu $M$, Rodriguez $H$. Free radical-induced damage to DNA: mechanisms and measurement. Free Radic Biol Med. 2002;32:1102-15.

64. Valko M, Izakovic M, Mazur M, Rhodes CJ, Telser J. Role of oxygen radicals in DNA damage and cancer incidence. Mol Cell Biochem. 2004;266:37-56.

65. Reuter S, Gupta SC, Chaturvedi MM, Aggarwal BB. Oxidative stress, inflammation, and cancer: how are they linked? Free Radic Biol Med. 2010;49:1603-16.

66. Fernandez A. Synergizing immunotherapy with molecular- targeted anticancer treatment. Drug Dis Today. 2014;19:1427-32.

67. Ser H-L, Ab Mutalib N-S, Yin W-F, Chan K-G, Goh B-H, Lee L-H. Evaluation of Antioxidative and cytotoxic activities of Streptomyces pluripotens MUSC137 isolated from mangrove soil in Malaysia. Front Microbiol. 2015;6:1398.

68. Ying X, Wang R, Xu J, Zhang W, Li H, Zhang C, et al. HPLC determination of eight polyphenols in the leaves of Crataegus pinnatifida Bge. Var. major. J Chromatogr Sci. 2009;47:201-5.

69. Terpinc P, Polak T, Šegatin N, Hanzlowsky A, Ulrih NP, Abramovic ${ }^{*}$ H. Antioxidant properties of 4-vinyl derivatives of hydroxycinnamic acids. Food Chem 2011;128: 62-68.

70. Brewer MS. Natural antioxidants: sources, compounds, mechanisms of action, and potential applications. Compr Rev Food Sci Food Saf. 201 1;10:221-47.

71. Camargo AEl, Daguer DAE, Barbosa DS. Green tea exerts antioxidant action in vitro and its consumption increases total serum antioxidant potential in normal and dyslipidemic subjects. Nutr Res. 2006;26:626-31.

\section{Submit your next manuscript to BioMed Central and we will help you at every step:}

- We accept pre-submission inquiries

- Our selector tool helps you to find the most relevant journal

- We provide round the clock customer support

- Convenient online submission

- Thorough peer review

- Inclusion in PubMed and all major indexing services

- Maximum visibility for your research

Submit your manuscript at www.biomedcentral.com/submit

) Biomed Central 